\title{
Sustainable Community Based Water Supply at Salatiga by Use of Rapfish Method
}

\author{
Suharyanto ${ }^{1, *}$, Angelica Deasy $\mathrm{K}^{2}$, and Sudarno ${ }^{3}$ \\ ${ }^{1}$ Department of Civil Engineering, Eng. Faculty, Diponegoro University, Semarang, Indonesia \\ ${ }^{2}$ Public Works Department, Salatiga Regency, Indonesia \\ ${ }^{3}$ Department of Environmental Engineering, Eng. Faculty, Diponegoro University, Semarang, Indonesia
}

\begin{abstract}
Sustainable water supply has been the United Nation's goal as stipulated in Sustainable Development Goals (SDG's). In 2030, all people must have acess to safe and affordable drinking water. In Salatiga Indonesia, the water supply company (PDAM) can now only serves $65.64 \%$ of the city's population. There are about $11.14 \%$ of the population served by community based water supply (CBWS). In line with the SDG's, The Government of Indonesia's program to have $100 \%$ coverage of water supply. The limitation on PDAM coverage has led the increase number of CBWS. This tendency has raised the question on the sustainability of CBWS. This paper presents the sustainability evaluations of some CBWS in Salatiga using Rapfish method. In the method, sustainability is evaluated using multi-dimensional scalling based on aspects of ecological, technological, social, institutional, and economical. The strategy to improve sustainability is identified using SWOT analysis. The study performed at 4 (four) CBWS at Kecamatan Sidorejo, Salatiga. It represents the CBWS using deep water sources and spring water sources. It shows that all CBWS analysed are barely sustainable on the dimension of ecological, technological, and social. The dimension on institutional and economical are in the status of no sustainability. Therefore, the CBWS need some improvement and reinforcement especially on institutional and economical.
\end{abstract}

\section{Introduction}

Sustainable water supply has been the United Nation's goal as stipulated in Sustainable Development Goals (SDG's). In 2030, all people must have acess to safe and affordable drinking water which are sustainable [1]. It is therefore needs to Support and strengthen the participation of local communities in improving water and sanitation services. In Salatiga Indonesia, the water supply company (PDAM) can now only serves about $65.64 \%$ of the city's population [2]. There are about $11.14 \%$ of the population which are served by community based water supply (CBWS) [2]. In line with the SDG's, The Government of Indonesia's program to have $100 \%$ coverage of water supply and the limitation on PDAM coverage services has led the increase number of the community based water supply. The role of CBWS in Indonesia have long been recognised and now becoming more significant. This tendency has raised the question on the sustainability of CBWS.

Currently, there are two framework in the analysis of the "health" status of water supply company (PDAM) which are published by BPPSPAM (Board of Development for Drinking Water Supply) and The Minsitry of Internal Affairs (Depdagri). However, those method are applicable for more formal companies such as PDAM. The evaluation framework for CBWS has not yet been defined.

This paper presents the sustainability evaluations of some CBWS in Salatiga City by use of Rapfish method [3]. The objectives of this research is to identify the sustainability status of some CBWS and formulate strategy for CBWS to achieve its sustainability by use of SWOT analysis [4].

\footnotetext{
"Corresponding author: suharyanto20@yahoo.co.id
} 


\section{Literatures Review}

\subsection{Community Based Water Supply}

Community based water supply (CBWS) has long been recognised in fulfiling water needs especially in remote areas where government water supply (PDAM) are not present. Currently, the Government of Indonesia has recognised the inseperable role of CBWS to meet people's water requirements in combined with the coverage of PDAM. CBWS is a water supply system which are constructed by the government but its operation management including its agreed tariffs performed by a community. The objectives of CBWS is to boost the coverage of water supply services and to stimulate community to participate in the services. In order to guarantee its successes, the participation of community in a CBWS must be started since its plannig, design, and its operation phase. A CBWS will cover the operation and maintenance costing. The government, however, still required to facilitate the preparation of management team for a CBWS, trained and prepared the management team.

A sustainable CBWS is a CBWS which can sustain its services continuously for long term. The management team of a CBWS should be able to manage its operation, collect tarrifs from users, and able to overcome the operation problems. A sustainable CBWS must satisfy the following criterias [5]:

1. In operation and fullfill its services.

2. Provide the services as planned in good quality, in sufficient quantity, accessible, reliable, continuous, and beneficials to users.

3. Can operate and function well for long term in accordance to the life-cycle of the designed system.

4. The management should attract and involving the community/users through formal institusion (community's institution such as Paguyuban), able to closely coordinate with gorvernment and other institutions (private) as needed.

5. The cost for operation, maintenance, repair, replacement, and administrative services are affordable and can be met with the user's fees or other sustainable financial supports.

6. Can be operated and maintained in the communitys' level of expertiese and resources, and accesed to outside support (technical, training, and monitoring).

7. Does not give negative environmental impacts.

\subsection{Rapfish Method}

The Rapfish method uses 5 dimension i.e., ecology, technology, social, institutional, and economy [6]. Each dimension is represented by usually 6-12 relevant attributes [7]. Application of The Rapfish method for each CBWS starts from the valuation (score) of each attribute. Multi dimensional scaling (MDS) analysis is then performed to access the status of sustainability in each dimension and overall sustainabillty status based on all dimension. The following are steps in the analysis using Rapfish method [8].

1. Attribute Scoring

Each attribute in each dimension indicating sustainability of water supply is given score 1 to 5 .

2. MDS Scaling and analysis.

The status of sustainability of each attribute is represented in the scale of 0 to 100 (from bad to very good). The result of MDS analysis is the state of a CBWS score of sustainability in each dimension and in overall. The category of sustainability is Not sustainable (score $<25$ ), Less Sustainable (score between 25 to 50), sustainable (score between 50 to 75), and very sustainable (score well over 75) [9].

3. Attribute Leverage

The attribute leverage is to assess which attribute have more significant roles in supporting sustainability in each dimension. It uses Jacknife like technique, where each time each attribute is dropped in the analysis. The percentage contribution of attribute can be assessed by the resulting root mean square (RMS) change in ordination when the attribute is dropped. The higher the RMS change when an attribute is dropped, shows the influence of this attribute is bigger. This is ussually called pareto calculation [10].

4. Monte Carlo Simulation

This analysis is to evaluate the influence of any deviation in the score valuation, discrepancies, and any subjectivity in the MDS proceses, including on the selection of attribute). The deviation between MDS versus Monter Carlo simulation should show comparable results, otherwise it indicates the existence of stresses in the MDS analysis [11]. 


\subsection{Criterias for Sustainability}

In 1999, the internal affair minister of Indonesia has published criterias for evaluating performances of PDAM as part of performance's audit for government companies [12]. The criterias used are financial, operational, and administrative aspects. Each aspect consists of several relevant attributes. Applied for each PDAM, based on the status or level on each attributes and some weighting on the scoring, the status or the condition of PDAM can be classified into Very Good, Good, Sufficient, Barely Sufficient, Not Good.

As the implementation of government's regulation No. 16/2005 about drinking water supply, the government has established BPPSAM (government board for development of drinking water supply). Currently BPPSPAM has published criterias to evaluate the "health status" of PDAM. It uses 4 (four) aspects, i.e., Financial, Services to Customers, Operational, and Human Resources [13]. Each aspect is further evaluated by several relevant attributes. Based on the state of each attribute in every aspect, the PDAM can be classified into three category of being "healthy", "less healthy", and "not healthy".

The above two frameworks of evaluation, however, applicable only to formal company such as PDAM where its management system has been prepared for accountable and professional services. For evaluation of a CBWS, it needs more open evaluation framework. In this paper, it uses a Rapfish method (Rapid Appraisal for fishery) [14]. The method is initially used and applied in fishery industries. However, the opennes of the method can be applied in any natural resources field with some justification on the evaluated aspects and attributes.

\section{Research Method}

The research method uses primary and secondary data collected from each CBWS studied. Primary data consist of questionair survey, interview, and field observation. Secondary data consist of data on legal aspects of the CBWS, its organisation (structures, rules, SOP, job description, etc.), activities of organisation, administrative and financial activites, consumer's role, and its reporting.

The analysis is performed using Rapfish method to access its sustainability and SWOT analysis to evaluate which strategy to improve each CBWS sustainability.

In this paper, some attributes used to access in each dimension is formulated by considering attributes on Permendagri and BPPSPAM. The following are attributes in each dimension which are used. In each attribute, it further supported by several parameters.

Table 1. Attributes in each dimenstion used

\begin{tabular}{|r|l|r|l|r|l|}
\hline \multicolumn{1}{|c|}{ No } & \multicolumn{1}{|c|}{ Dimension/ Attribute } & \multicolumn{1}{|c|}{ No. } & \multicolumn{1}{|c|}{ Dimension/Atttribute } & No. & Dimension/Atttribute \\
\hline I & Ecological & III & Social & V & Economical \\
\hline 1. & Water Quality & 1. & Community's Behaviour & 1. & Profit \\
\hline 2. & Water Consumption & 2. & Social Participation & 2. & Revenue Effectivity \\
\hline 3. & $\begin{array}{l}\text { Available Water } \\
\text { discharge }\end{array}$ & 3. & $\begin{array}{l}\text { Maintenance of } \\
\text { infrastructures }\end{array}$ & 4. & Development Allocation \\
\hline 4. & $\begin{array}{l}\text { Environment Protection } \\
\text { on water source }\end{array}$ & 4. & $\begin{array}{l}\text { Ability to maintain } \\
\text { infrastructures }\end{array}$ & Community's Wellfare \\
\hline 5. & Maintenance water source & 5. & Ability to pay & Cost for OM \\
\hline 6. & Impact to Environment & 6. & Willingness to pay & & \\
\hline 7. & Number of rainy days & 7. & Consumers' Earning & & \\
\hline 8. & Continuity & IV & Institutional & & \\
\hline II & Technological & 1. & Legality of management & & \\
\hline 1. & Complexity & 2. & Cooperation & & \\
\hline 2. & Spareparts & 3. & SOP & & \\
\hline 3. & Operation and & 4. & $\begin{array}{l}\text { Job Description and } \\
\text { Planning }\end{array}$ & & \\
\hline 4. & Maintenance & 5. & Working Schedule & & \\
\hline 5. & Customer's increase & 6. & $\begin{array}{l}\text { Internal and External } \\
\text { Reporting }\end{array}$ & & \\
\hline 6. & Coverage & 7. & Services to customer & & \\
\hline 7. & Customer coverage & 8. & Satisfaction of customers & & \\
\hline
\end{tabular}




\section{Analysis and Discussion}

\subsection{Description of CBWS studied}

The research is performed to 4 (four) CBWS in two Kelurahan at Salatiga City, each represents a deep well and a spring water sources such as shown in Table 2. It is expected to demonstrate whether the source of water has some influences on the sustainability of a CBWS.

Table 2. List of Community Based Water Supply (CBWS) at Salatiga Studied

\begin{tabular}{|c|c|c|c|c|c|c|c|c|c|}
\hline No & CBWS & Kelurahan & $\begin{array}{l}\text { Source } \\
\text { of } \\
\text { Water }\end{array}$ & $\begin{array}{c}\text { Users } \\
\text { (house) }\end{array}$ & SOP & Reporting & $\begin{array}{c}\text { Management } \\
\text { team }\end{array}$ & $\begin{array}{c}\text { Daily } \\
\text { Operational }\end{array}$ & $\begin{array}{c}\text { Returned } \\
\text { Quest. }\end{array}$ \\
\hline 1. & $\begin{array}{l}\text { Tirta } \\
\text { Barokah }\end{array}$ & $\begin{array}{l}\text { Sidorejo } \\
\text { Lor }\end{array}$ & $\begin{array}{l}\text { Deep } \\
\text { Well }\end{array}$ & 168 & No & $\begin{array}{c}\text { Internal, it } \\
\text { has } 2,660 \\
\text { US\$ in } \\
\text { their } \\
\text { account }\end{array}$ & $\begin{array}{c}\text { Head, } \\
\text { Secretary, } \\
\text { Treasury, } \\
\text { Technician, } \\
\text { Field staffs. }\end{array}$ & $\begin{array}{c}\text { Head, } \\
\text { Treasury, } \\
\text { Field staffs. }\end{array}$ & 60 \\
\hline 2. & $\begin{array}{l}\text { Tirta } \\
\text { Sejahtera }\end{array}$ & $\begin{array}{l}\text { Sidorejo } \\
\text { Lor }\end{array}$ & Spring & 120 & $\begin{array}{l}\text { Available, } \\
\text { but not fully } \\
\text { implemented }\end{array}$ & $\begin{array}{l}\text { Internal, it } \\
\text { has } 350 \\
\text { US\$ in } \\
\text { their acount }\end{array}$ & $\begin{array}{c}\text { Head, } \\
\text { Secretary, } \\
\text { Treasury, } \\
\text { Field staffs. }\end{array}$ & $\begin{array}{c}\text { Head, } \\
\text { Treasury, } \\
\text { Field staffs. }\end{array}$ & 49 \\
\hline 3. & $\begin{array}{l}\text { Tirta } \\
\text { Kamandanu }\end{array}$ & $\begin{array}{l}\text { Kauman } \\
\text { Kidul }\end{array}$ & $\begin{array}{l}\text { Deep } \\
\text { Well }\end{array}$ & 160 & No & $\begin{array}{c}\text { No Internal } \\
\text { reporting }\end{array}$ & $\begin{array}{c}\text { Head, } \\
\text { Secretary, } \\
\text { Treasury, } \\
\text { Technician, }\end{array}$ & Head do all & 20 \\
\hline 4. & $\begin{array}{l}\text { Tirto } \\
\text { Agung }\end{array}$ & $\begin{array}{l}\text { Kauman } \\
\text { Kidul }\end{array}$ & Spring & 40 & No & $\begin{array}{c}\text { No Internal } \\
\text { reporting }\end{array}$ & $\begin{array}{c}\text { Head, } \\
\text { Secretary, } \\
\text { Treasury, } \\
\text { and } \\
\text { Technician }\end{array}$ & $\begin{array}{c}\text { Head } \\
\text { handles all }\end{array}$ & 39 \\
\hline
\end{tabular}

\subsection{Results of MDS in Rapfish Method}

The results of MDS analysis for each dimension is shown in Figure 1 to 5. In Figure 1, based on the dimension Ecology, all CBWS are in good sustainability. It indicates that the management put efforts in maintaining and protecting water sources and its water abstraction are below yield capacity.

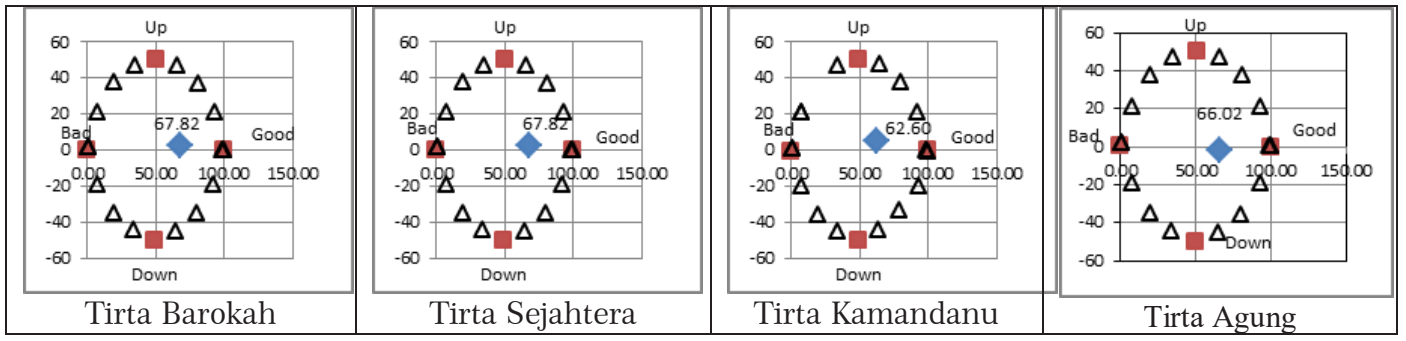

Fig 1. Sustainability Status Based on Ecological Dimension

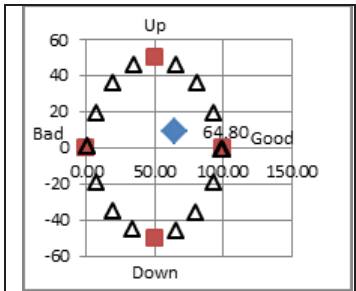

Tirta Barokah

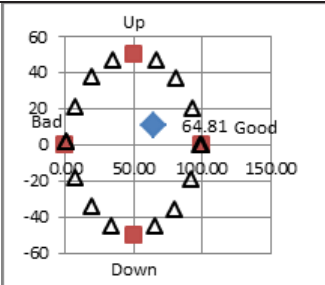

Tirta Sejahtera

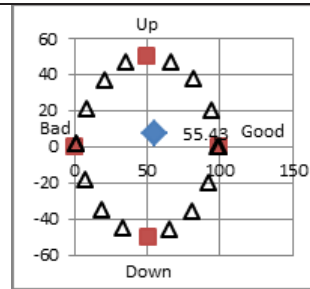

Tirta Kamandanu

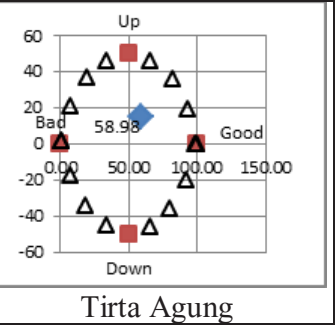

Fig 2. Sustainability Status Based on Technological Dimension 


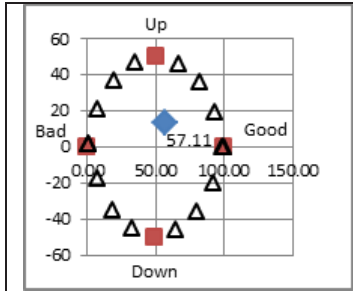

Tirta Barokah

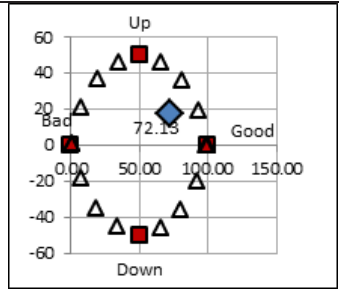

Tirta Sejahtera

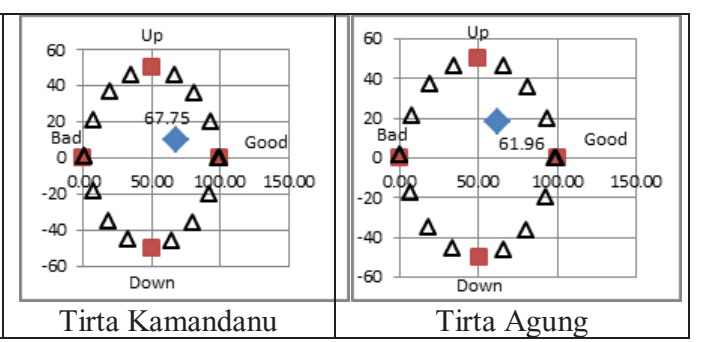

Fig 3. Sustainability Statuses based on Social Dimension.
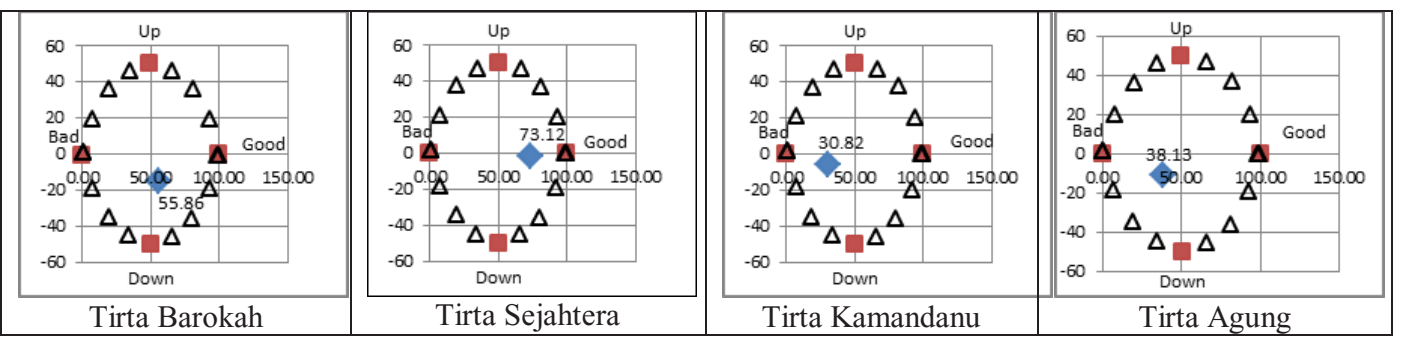

Fig 4. Sustainability Status Based on Institutional Dimension

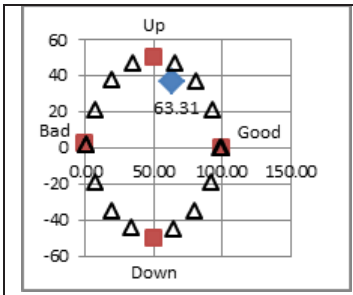

Tirta Barokah

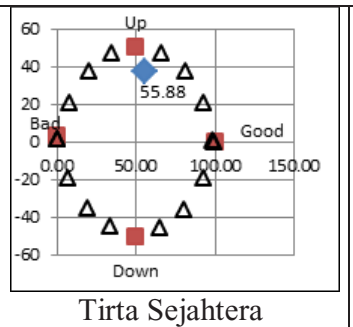

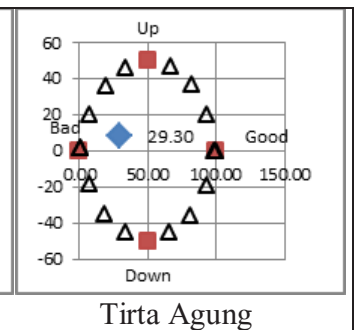

Tirta Kamandanu

Tirta Agung

Fig 5. Sustainability Status Based on Economic Dimension.

From the point of view Technological Dimension (Figure 2), Tirta Barokah and Tirta Sejahtera poses good (sustainable status). CBWS Tirta Kamandanu and Tirta Agung has reached sustainable status, which are barely over 50 .

From Social Dimension (Figure 3), all the CBWS are in good sustainable status. It shows that the community support the existence of all CBWS. They are active in maintaining its facilities, and eager participating for the maintenance, as well as tariffs' payment. This situation is a very good modal for developing and increasing the sustainability of any CBWS.

Figure 4 shows the Institutional Dimension. It shows that Tirta Barokah and Tirta Sejahtera are in sustainable status (over 50 score). Meanwhile, Tirta Kamandanu and Tirta Agung are very low (not sustainable status), ecah obtain 30.82 and 38.64. This result is also reflected that the management team does not functioning properly. There is only one person who is active currently.

Furthemore, the dimension of Economic such as shown in Figure 5, shows that Tirta Barokah and Tirta Sejahtera are in sustainable status. However, Tirta Kamandanu and Tirta Agung has low sustainability (Not Sustainable status), since it has low score of 28.57 and 29.30 respectively.

Overall, Tirta Barokah and Tirta Sejahtera are in sustainable status with MDS score are all over 50 which allow them to develop further. The Tirta Kamandanu and Tirta Agung are still having problem internally (institutional and economic), which cause them to be in the status of not sustainable

\subsection{Sensitivity Using Monte Carlo Simulation}

The Monte Carlo simulation result show minor discrepancies (less than $1.5 \%$ of discrepancies) compared with the result of MDS analysis. It shows that the attributes and its scoring are consistent the results does not influenced by any random error. 


\section{Conclusion and Recommendation}

1. It shows that the MDS method within the Rapfish method can be comprehensively applied in accessing sustainability area wide including in water supply.

2. The type of source water (deep well or springs) does not have significant (determining factor) guaranteeing sustainable CBWS. Rather, it more dependent to its management practices.

3. CBWS Tirta Barokah (using deep well) and Tirta Sejahtera (using springs water) are two CBWS which are currently can be said to be on the right track of sustainability as indicated by the score of each dimension reaches over 50 . They are also having some distingusing features as well which are the modal for further development. The strategy recommended is to focus on maintaining the management practices and more improvements on its operational aspects in order to gain more strengths.

4. CBWS Tirta Kamandanu (using deep well) and Tirta Agung (using springs) show that these CBWS has not run well as indicated that the score in dimension of institution and economics are far below 50. It needs urgent improvement on the dimension of institution (organisation, job description, and its management, etc.) and on the dimension of economic. The recommended strategy is changing the current management practices overcoming the weaknesses, seek assistance and facilitation from outside institutions (government institution).

\section{References}

1. UNDP, Sustainable Development Goals : 17 Goals to Transform our World, http://www.un.org/sustainabledevelopment/water-and-sanitation/ (accessed 20 May 2017).

2. Badan Pusat Statistik. Kota Salatiga Dalam Angka (2016).

3. Tony J. Pitcher. RAPFISH : Rapid Appraisal Technique for Fisheries, and its Application to the Code of Conduct for Responsible Fisheries. Food and Agriculture Organization of the United nations, Rome (1999).

4. Sayed M. N. U., Zifu Li, Heinz-Peter mang. A strengths, weaknesses, opportunities, and threats analysis on integrating safe water supply and sustainable sanitation systems, Journal of Water, Sanitation and Hygiene for Development 4(3):437-448. September (2014).

5. Brikké, François dan Bredero, Maarten. Linking Technology Choice with Operation and Maintenance in The Context of Community Water Supply and Sanitation. Health Organization and IRC Water and Sanitation Centre (2003).

6. Castro, Vivian. Sustainable Community Management of Urban Water and Sanitation Schemes. Water and Sanitation Program - Africa, World Bank. Nairobi, Kenya (2009).

7. Fauzi A and S Anna. Pemodelan Sumberdaya Perikanan dan Kelautan Untuk Analisis Kebijakan. Penerbit Gramedia Pustaka Utama. Jakarta (2005).

8. Castro, Vivian. Sustainable Community Management of Urban Water and Sanitation Schemes. Water and Sanitation Program - Africa, World Bank. Nairobi, Kenya (2009).

9. Hasim., A. Sapei., S. Budiharsono and Y. Wardiatno. Analisis Status Keberlanjutan Untuk Pengembangan Pengelolaan Pada Danau Limboto Provinsi Gorontalo. Prosiding Seminar Nasional Limnologi VI. Program Studi Pengelolaan Sumberdaya Alam dan Lingkungan. Institut Pertanian Bogor. Bogor (2012).

10. Kusbimanto, I.W. Sitorus, S.R.P. Machfud. Poerwo. I.F.P, and Yani M. Analisis Keberlanjutan Pengembangan Prasarana Transportasi Perkotaan di Metropolitan Minasata Provinsi Sulawesi Selatan . Jurnal Jalan-Jembatan. Penerbit Puslitbang Jalan dan jembatan Badan Litbang, Kementerian Pekerjaan Umum. 30(1). (2013).

11. Kavanagh, P. Rapid Appraisal of Fisheries (Rapfish) Project. Rapfish Software Description (For Microsoft Exel). University of British Columbia. Fishries Centre. Vancouver (2001).

12. Kepmendagri No. 47 Tahun 1999 tentang Pedoman Penilaian Kinerja PDAM.

13. Kemen PU BPPSPAM. 2010. Petunjuk Teknis Penilaian Kinerja PDAM. 